\title{
Statistical Optimization of Production Conditions of Alkaline Pectin Lyase from Bacillus cereus using Response Surface Methodology
}

Reena $\mathbf{G}^{*}$, Pooja K and Nitish S

Department of Biotechnology, Himachal Pradesh University, Shimla, India

\begin{abstract}
Pectin lyase finds applications in the degumming and retting of plant fibers where it degrades highly methylesterified pectin without prior action of any other pectinase. Response surface methodology (RSM) has been frequently utilized for the optimization of production process of industrially important enzymes from microbes. In the present work, fermentation conditions for the production of pectin lyase from Bacillus cereus were optimized using the factorial and central composite design of RSM. The cubic order polynomial regression model was found to be adequate and significant with a determination coefficient $R^{2}$ of 0.9505 $(p<0.0001)$. The ANOVA analysis and three dimensional surface plots confirmed interaction among variables. The optimum values of variables were found to be pectin $4 \%(\mathrm{w} / \mathrm{v})$, sodium carbonate $1 \%(\mathrm{w} / \mathrm{v})$, manganese sulfate $0.055 \%(\mathrm{w} / \mathrm{v})$ and magnesium sulfate $0.018 \%(\mathrm{w} / \mathrm{v})$ at $150 \mathrm{rpm}$ under response surface curves. After optimization, the experimental value of maximum activity of enzyme $(3.37 \mathrm{U} / \mathrm{ml})$ was found higher but close to the predicted value $(2.68 \mathrm{U} / \mathrm{ml})$ and the enzyme activity increased by 1.32 fold $(32.16 \%)$.
\end{abstract}

Keywords: Pectin lyase; RSM (Response Surface Methodology); Plackett-Burman design; CCD (Central Composite Design); Pareto Chart; Regression analysis; Production

\section{Introduction}

Pectin is a hetero-polysaccharide which is made up of D-galacturonic acid residues linked through $\alpha-(1-4)$ linkage and esterified with methanol at the carboxylic groups based on their degree of esterification [1]. A major fraction of the primary wall of dicots and non-graminaceous monocots is pectin that accounts for as much as $30 \%$ of the total polysaccharides [2]. Pectinases degrade pectin, a high molecular weight acid polysaccharide consisting of a-(1-4) linked D-galacturonic acid residues [3], present in the middle lamella of plant cell wall. Pectinolytic enzymes have various classes and sub-classes depending upon their substrate specificity and mode of action for example methyl de-esterases, hydrolases and lyases. Among all pectinases, pectin lyases (E.C.4.2.2.10) are of great importance, because they degrade pectin polymers by $\beta$-elimination mechanism that results in the formation of 4,5-unsaturated oligogalacturonides while other pectinases degrade pectin molecule completely by acting sequentially [1]. Pectinases are used in processes such as degumming of plant fibers, scouring of cotton fibers, retting of flex, where removal of pectic substances is necessary such as to avoid imperfections in dyeing, water absorbency and whiteness of cotton due to criss-crossed structure of pectin and also to study the structure of pectin [4]. Pectin lyase produced by Aspergillus flavus MTCC 7589 was for the first time used in retting of sunn hemp (Crotolaria juncea) [5]. In a recent study, it has been found that extracted pectin could be used as a medium for encapsulation of some bioactive compound viz., crocin, picrocrocin, and saffrana [6]. In view of this, the present investigation was carried out to optimise conditions for maximum production and activity of alkaline pectin lyase from Bacillus cereus in a cost effective manner. In a recent research work, different substrates were evaluated for optimum and cheap production of pectate lyase from Erwinia chrysanthemi Ec9 and highest yield of pectate lyase was obtained using basal medium containing lemon peel extract and yeast extract [7]. Any enzymatic process runs under multiple variables and changes in these variables decide the yield of process. Each process variable can be optimized and studied manually but study of cumulative impact of all the variables is tedious and laborious work. Moreover, the inability of conventional methods to explain the extent of effect of process parameters in biotechnology has led to the use of statistical methods [8]. Response surface methodology (RSM) is a statistical analysis of the impact of different process variables on production process and also displays the interaction of different variables with each other at a time [9]. Several statistical models are used in RSM to evaluate the effect of independent variables on the desired variable response [10]. The RSM has been applied as an experimental strategy for seeking the optimum conditions in a multivariable system [11]. The randomized experiments have to be performed in order to minimize the effects of unexplained variability in the actual responses due to extraneous factors [12]. Lately, many studies have applied this technique for the production of industrially important enzymes such as cyanide degradation ability of bacterial consortium was enhanced by the statistical methods of optimization [13]. Similarly, culture conditions have been optimized for enhanced production of protease from Bacillus subtilis [14]. RSM being less laborious and timeconsuming has been applied successfully in biotechnological processes to decreases the number of experimental trials [15]. Keeping in view this, the present investigation was carried out with the aim to reveal interactions among different production parameters and to optimize them for pectin lyase production from Bacillus cereus using RSM. The optimum conditions during the pectinase extraction procedure could improve the enzymatic characteristics of the enzyme and protect its activity and stability [16].

\section{Material and Methods}

\section{Chemicals}

Pectin and all other chemicals used in the study were of analytical

*Corresonding author: Reena G, Department of Biotechnology, Himachal Pradesh University, Shimla, India, Tel: 911772831948; E-mail: reenagupta_2001@yahoo.com

Received August 02, 2016; Accepted August 24, 2016; Published August 29, 2016

Citation: Reena G, Pooja K, Nitish S (2016) Statistical Optimization of Production Conditions of Alkaline Pectin Lyase from Bacillus cereus using Response Surface Methodology. J Food Ind Microbiol 2: 113. doi:10.4172/2572-4134.1000113

Copyright: @ 2016 Reena G, et al. This is an open-access article distributed under the terms of the Creative Commons Attribution License, which permits unrestricted use, distribution, and reproduction in any medium, provided the original author and source are credited. 
Citation: Reena G, Pooja K, Nitish S (2016) Statistical Optimization of Production Conditions of Alkaline Pectin Lyase from Bacillus cereus using Response Surface Methodology. J Food Ind Microbiol 2: 113. doi:10.4172/2572-4134.1000113

grade and procured from Sigma Aldrich (U.S.A) and Himedia, Mumbai, India.

\section{Microorganism and enzyme production}

Bacillus cereus isolated from the soil sample was used as the source for pectin lyase production. The inoculum was prepared in seed medium that contained pectin $1 \%(\mathrm{w} / \mathrm{v})$, peptone $0.5 \%(\mathrm{w} / \mathrm{v})$, yeast extract $0.5 \%(\mathrm{w} / \mathrm{v})$, di-potassium hydrogen phosphate $0.1 \%(\mathrm{w} / \mathrm{v})$, magnesium sulphate $0.02 \%(\mathrm{w} / \mathrm{v})$, sodium carbonate $0.6 \%(\mathrm{w} / \mathrm{v})$ in 250 $\mathrm{ml}$ flask. The flask was then incubated for $18 \mathrm{~h}$ with continuous shaking $(130 \mathrm{rpm})$ at $35^{\circ} \mathrm{C}$. From seed culture, $1 \mathrm{ml}$ was inoculated into $50 \mathrm{ml}$ of production medium that contained per liter, pectin $30 \mathrm{~g}$, polypeptone $5 \mathrm{~g}$, yeast extract $5 \mathrm{~g}, \mathrm{MgSO}_{4} \cdot 7 \mathrm{H}_{2} \mathrm{O} 0.2 \mathrm{~g}, \mathrm{MnSO}_{4} \cdot 7 \mathrm{H}_{2} \mathrm{O} 0.05 \mathrm{~g}, \mathrm{~K}_{2} \mathrm{HPO}_{4}$ $1 \mathrm{~g}, \mathrm{Na}_{2} \mathrm{CO}_{3} 10 \mathrm{~g}$. The inoculated production medium $(\mathrm{pH} 10.5)$ was incubated for $24 \mathrm{~h}$ in incubator shaker $(130 \mathrm{rpm})$ at $35^{\circ} \mathrm{C}$. Production medium was centrifuged at $12,000 \mathrm{rpm}$ for $10 \mathrm{~min}$. The supernatant was collected and used for determining pectin lyase activity.

\section{Pectin lyase assay}

Pectin lyase assay was performed by spectrophotometric method [17], using pectin as substrate and TBA (thiobarbituric acid) as coloring agent at $550 \mathrm{~nm}$. One unit of enzyme activity was defined as the amount of enzyme which formed $1 \mu \mathrm{mol} / \mathrm{ml}$ of unsaturated galacturonic acid per min with a molar extinction coefficient of $5500 \mathrm{M}^{-1} \mathrm{CM}^{-1}$.

\section{Experimental design}

The RSM was used to investigate the effect of combined interactions of twelve independent production variables on the pectin lyase production from Bacillus cereus. These were concentration of pectin, peptone, yeast extract, sodium carbonate, di-potassium hydrogen phosphate, magnesium sulphate, manganese sulphate, incubation temperature, incubation time, inoculum size, $\mathrm{pH}$ and agitation rate. The RSM was carried out using Plackett-Burman and Central composite designs (CCD) of Design expert software (version 9.0.4).

Plackett-Burman analysis: In Plackett-Burman analysis, twelve different production variables were screened for responses (enzyme activity) at two levels i.e. minimum and maximum. The upper and lower limits of each variable were chosen by enzyme characteristics and the preliminary investigations. The effect of each variable was calculated using the following equation:

$$
\left[\mathrm{E}=\left(\Sigma \mathrm{M}_{+}-\Sigma \mathrm{M}\right) / \mathrm{N}\right]
$$

Where, $\mathrm{E}$ is the effect of the tested variable and $\mathrm{M}_{+}$and $\mathrm{M}_{-}$are responses (enzyme activity) of trials at which the parameter was at its higher and lower levels respectively and $\mathrm{N}$ is the number of experiments carried out [18].

Central composite design (CCD): Different independent variables which showed positive effect on the production of pectin lyase were further optimized using CCD [19] to analyze the optimum level and combined effect of variables. Using CCD different regression models were used to interpret the data and to generate response surfaces. Effects of interactions of various parameters on the pectin lyase production was studied by plotting three dimensional response curves against any two independent variables while keeping the other independent variables at their ' 0 ' levels.

\section{Validation of statistical model}

The statistical model was validated for the production of pectin lyase by performing at shake flask under predicted set of conditions. The lack of fit statistics was used to test the adequacy and efficiency of the model.

\section{Results and Discussion}

\section{Plackett-Burman analysis}

The different experimental combinations of variables were obtained using the Plackett-Burman design and the study was carried out in 20 runs Table 1 . A set of 20 combinations exhibited variation in activity ranging from 0.06 to $1.47 \mathrm{U} / \mathrm{ml}$ and run 13 was found to be the most appropriate combination and gave maximum activity of $1.47 \mathrm{U} /$ $\mathrm{ml}$. Results obtained from Plackett-Burman analysis were further used to construct a Pareto chart Figure 1 to find out the order of significance

\begin{tabular}{|c|c|c|c|c|c|c|c|c|c|c|c|c|c|}
\hline Run & $\begin{array}{l}\text { Pectin } \\
(\%)\end{array}$ & $\begin{array}{c}\text { Peptone } \\
(\%)\end{array}$ & $\begin{array}{c}\text { Yeast } \\
\text { Extract (\%) }\end{array}$ & $\begin{array}{c}\mathrm{MnSO}_{4} \\
(\%)\end{array}$ & $\begin{array}{c}\mathrm{MgSO}_{4} \\
(\%)\end{array}$ & $\mathrm{K}_{2} \mathrm{HPO}_{4}(\%)$ & $\begin{array}{c}\text { Inoculum } \\
\text { Size (\%) }\end{array}$ & $\mathrm{pH}$ & $\begin{array}{c}\text { Incubation } \\
\text { Time (h) }\end{array}$ & $\begin{array}{c}\text { Temperature } \\
(\circ \mathbf{C})\end{array}$ & $\begin{array}{c}\mathrm{Na}_{2} \mathrm{CO}_{3} \\
(\%)\end{array}$ & $\begin{array}{c}\text { Agitation rate } \\
(\mathrm{rpm})\end{array}$ & $\begin{array}{c}\text { Response } \\
(\mathrm{U} / \mathrm{ml})\end{array}$ \\
\hline 1 & 1 & 0.1 & 0.1 & 0.002 & 0.009 & 0.08 & 1 & 8 & 12 & 30 & 0.8 & 130 & 0.84 \\
\hline 2 & 1 & 1 & 0.1 & 0.008 & 0.009 & 0.08 & 1 & 8 & 36 & 50 & 0.8 & 170 & 0.77 \\
\hline 3 & 5 & 0.1 & 0.1 & 0.008 & 0.04 & 0.3 & 3 & 8 & 36 & 30 & 1.2 & 130 & 0.55 \\
\hline 4 & 5 & 0.1 & 1 & 0.002 & 0.04 & 0.08 & 1 & 8 & 12 & 50 & 1.2 & 130 & 1.3 \\
\hline 5 & 1 & 1 & 1 & 0.008 & 0.04 & 0.08 & 3 & 8 & 36 & 30 & 0.8 & 130 & 0.29 \\
\hline 6 & 1 & 0.1 & 0.1 & 0.002 & 0.04 & 0.3 & 1 & 12 & 36 & 30 & 0.8 & 170 & 0.42 \\
\hline 7 & 5 & 1 & 0.1 & 0.002 & 0.04 & 0.3 & 3 & 12 & 12 & 50 & 0.8 & 170 & 0.74 \\
\hline 8 & 5 & 0.1 & 1 & 0.002 & 0.009 & 0.08 & 1 & 12 & 36 & 30 & 1.2 & 170 & 0.16 \\
\hline 9 & 1 & 1 & 0.1 & 0.002 & 0.009 & 0.08 & 3 & 12 & 12 & 50 & 1.2 & 130 & 0.15 \\
\hline 10 & 5 & 1 & 1 & 0.002 & 0.04 & 0.08 & 3 & 8 & 12 & 30 & 0.8 & 170 & 0.17 \\
\hline 11 & 1 & 1 & 1 & 0.002 & 0.04 & 0.3 & 1 & 8 & 36 & 50 & 1.2 & 170 & 0.3 \\
\hline 12 & 5 & 0.1 & 1 & 0.008 & 0.009 & 0.08 & 3 & 12 & 36 & 50 & 0.8 & 170 & 0.39 \\
\hline 13 & 1 & 0.1 & 0.1 & 0.008 & 0.04 & 0.08 & 3 & 12 & 12 & 30 & 1.2 & 170 & 1.47 \\
\hline 14 & 1 & 0.1 & 1 & 0.008 & 0.04 & 0.3 & 1 & 12 & 12 & 50 & 0.8 & 130 & 0.28 \\
\hline 15 & 1 & 1 & 1 & 0.002 & 0.009 & 0.3 & 3 & 12 & 36 & 30 & 1.2 & 130 & 0.14 \\
\hline 16 & 5 & 0.1 & 0.1 & 0.002 & 0.009 & 0.3 & 3 & 8 & 36 & 50 & 0.8 & 130 & 0.44 \\
\hline 17 & 5 & 1 & 0.1 & 0.008 & 0.009 & 0.3 & 1 & 8 & 12 & 30 & 1.2 & 170 & 1.36 \\
\hline 18 & 5 & 1 & 0.1 & 0.008 & 0.04 & 0.08 & 1 & 12 & 36 & 50 & 1.2 & 130 & 0.65 \\
\hline 19 & 1 & 0.1 & 1 & 0.008 & 0.009 & 0.3 & 3 & 8 & 12 & 50 & 1.2 & 170 & 0.06 \\
\hline 20 & 5 & 1 & 1 & 0.008 & 0.009 & 0.3 & 1 & 12 & 12 & 30 & 0.8 & 130 & 0.27 \\
\hline
\end{tabular}

Table 1: Plackett-Burman experimental design for evaluating the influence of various independent variables on the production of pectin lyase from Bacillus cereus. 


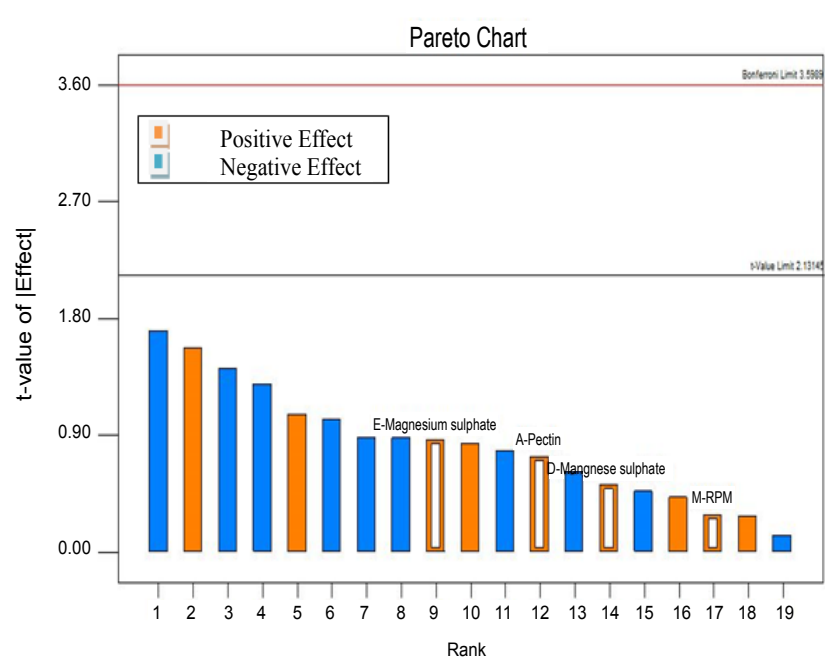

Figure 1: The Pareto chart showing the effect of different factors on the production of pectin lyase from Bacillus cereus.

of variables on pectin lyase production. It was evident from the Pareto chart that the concentration of pectin, sodium carbonate, manganese sulfate, magnesium sulfate and agitation rate showed positive effect and thus had significant effect on pectin lyase production from Bacillus cereus. Similarly, in a previous study pectinase production from Bacillus subtilis WSHB04-02 was optimized using RSM and results showed that only $\mathrm{pH}$ had significant impact on pectinases production [20]. In an another study, it had also been shown that temperature and $\mathrm{pH}$ were significant factors influencing pectate lyase production from Paenibacillus polymyxa N10 [21].

\section{Central composite design (CCD)}

A total of 50 experimental combinations Table 2 were obtained using CCD for five positive variables (concentration of pectin, sodium carbonate, manganese sulfate, magnesium sulfate and agitation rate). In other study, effects of three main variables $\mathrm{pH}$, temperature and inoculum size were evaluated on amylase production using full factorial CCD [22]. The data obtained from CCD was used to generate the ANOVA Table 3 which showed that the lack of fit was non-significant and experimental data was highly reliable. The cubic process order proved best and ANOVA demonstrated that the model was highly significant $(\mathrm{p}<0.0001)$ Table 4 . The $3 \mathrm{D}$ response graphs were generated for regression analysis of CCD design data using pair wise combination of five positive factors for pectin lyase production Figures 2-5.The response surface plots were more or less hill shaped and showed interactions among variables with an optimum activity around concentration of pectin $4 \%(\mathrm{w} / \mathrm{v})$, sodium carbonate $1 \%(\mathrm{w} / \mathrm{v})$, manganese sulfate $0.055 \%(\mathrm{w} / \mathrm{v})$ and $150 \mathrm{rpm}$. The predicted optimal value can be found from the estimated surface if the surface is shaped like a hill, if the estimated surface is more complicated then shape of the surface can be analyzed to indicate the directions in which new experiments should be performed [23]. In contrast, another study carried out to optimize the bioscouring conditions of alkaline pectinase from Bacillus WSHB04-02 showed no significant interactions between variables [20]. Pectin had the most distinct impact on enzyme production in comparison to other variables as the pectin is inducer for the production of pectin lyase. This finding is in consensus with the results of other studies for increasing enzyme production using RSM [24]. The agitation rate must be in optimal range because higher

\begin{tabular}{|c|c|c|c|c|c|c|c|}
\hline Std & Run & $\begin{array}{l}\text { Pectin } \\
(\%)\end{array}$ & $\begin{array}{c}\mathrm{Na}_{2} \mathrm{CO}_{3} \\
(\%)\end{array}$ & $\begin{array}{c}\mathrm{MnSO}_{4} \\
(\%)\end{array}$ & $\begin{array}{c}\mathrm{MgSO}_{4} \\
(\%)\end{array}$ & $\begin{array}{l}\text { Agitation } \\
\text { rate (rpm) }\end{array}$ & $\begin{array}{c}\text { Response } \\
\text { (U/ml) }\end{array}$ \\
\hline 13 & 1 & 4 & 0.6 & 0.1 & 0.029 & 130 & 0.63 \\
\hline 7 & 2 & 8 & 1.4 & 0.1 & 0.008 & 130 & 0.72 \\
\hline 1 & 3 & 4 & 0.6 & 0.01 & 0.008 & 130 & 0.45 \\
\hline 48 & 4 & 0 & 1 & 0.055 & 0.0185 & 150 & 0 \\
\hline 17 & 5 & 4 & 0.6 & 0.01 & 0.008 & 170 & 0.34 \\
\hline 3 & 6 & 4 & 1.4 & 0.01 & 0.008 & 130 & 1.2 \\
\hline 31 & 7 & 0 & 1.4 & 0.1 & 0.029 & 170 & 0 \\
\hline 12 & 8 & 4 & 1.4 & 0.01 & 0.029 & 130 & 1.3 \\
\hline 2 & 9 & 4 & 0.6 & 0.01 & 0.008 & 130 & 0.68 \\
\hline 49 & 10 & 0 & 1 & 0.055 & 0.0185 & 150 & 0 \\
\hline 10 & 11 & 0 & 0.6 & 0.01 & 0.029 & 130 & 0 \\
\hline 32 & 12 & 8 & 1.4 & 0.1 & 0.029 & 170 & 0.82 \\
\hline 22 & 13 & 4 & 0.6 & 0.1 & 0.008 & 170 & 1.5 \\
\hline 8 & 14 & 0 & 1.4 & 0.1 & 0.008 & 130 & 0 \\
\hline 24 & 15 & 8 & 1.4 & 0.1 & 0.008 & 170 & 0.68 \\
\hline 38 & 16 & 8 & 1 & 0.1 & 0.0185 & 150 & 0.82 \\
\hline 30 & 17 & 8 & 0.6 & 0.1 & 0.029 & 170 & 0.52 \\
\hline 6 & 18 & 8 & 0.6 & 0.1 & 0.008 & 130 & 0.42 \\
\hline 14 & 19 & 8 & 0.6 & 0.1 & 0.029 & 130 & 0.18 \\
\hline 42 & 20 & 4 & 1 & 0.055 & 0.0185 & 197.57 & 3.37 \\
\hline 15 & 21 & 0 & 1.4 & 0.1 & 0.029 & 130 & 0 \\
\hline 25 & 22 & 4 & 0.6 & 0.01 & 0.029 & 170 & 2.01 \\
\hline 4 & 23 & 8 & 1.4 & 0.01 & 0.008 & 130 & 0.71 \\
\hline 5 & 24 & 0 & 0.6 & 0.1 & 0.008 & 130 & 0 \\
\hline 27 & 25 & 8 & 1.4 & 0.01 & 0.029 & 170 & 0.89 \\
\hline 21 & 26 & 0 & 0.6 & 0.1 & 0.008 & 170 & 0 \\
\hline 28 & 27 & 4 & 1.4 & 0.01 & 0.029 & 170 & 1.82 \\
\hline 46 & 28 & 8 & 1 & 0.055 & 0.0185 & 150 & 0.99 \\
\hline 9 & 29 & 4 & 0.6 & 0.01 & 0.029 & 130 & 0.92 \\
\hline 36 & 30 & 0 & 1.9513657 & 0.055 & 0.0185 & 150 & 0 \\
\hline 47 & 31 & 0 & 1 & 0.055 & 0.0185 & 150 & 0 \\
\hline 39 & 32 & 0 & 1 & 0.055 & -0.0065 & 150 & 0 \\
\hline 19 & 33 & 4 & 1.4 & 0.01 & 0.008 & 170 & 1.78 \\
\hline 34 & 34 & 0 & 1 & 0.055 & 0.0185 & 150 & 0 \\
\hline 50 & 35 & 8 & 1 & 0.055 & 0.0185 & 150 & 1.11 \\
\hline 33 & 36 & 8 & 1 & 0.055 & 0.0185 & 150 & 1.2 \\
\hline 40 & 37 & 8 & 1 & 0.055 & 0.0435 & 150 & 0.31 \\
\hline 37 & 38 & 0 & 1 & -0.0520 & 0.0185 & 150 & 0 \\
\hline 16 & 39 & 4 & 1.4 & 0.1 & 0.029 & 130 & 1.3 \\
\hline 11 & 40 & 4 & 1.4 & 0.01 & 0.029 & 130 & 1.27 \\
\hline 44 & 41 & 0 & 1 & 0.055 & 0.0185 & 150 & 0 \\
\hline 26 & 42 & 8 & 0.6 & 0.01 & 0.029 & 170 & 0.48 \\
\hline 41 & 43 & 0 & 1 & 0.055 & 0.0185 & 102.43 & 0 \\
\hline 18 & 44 & 8 & 0.6 & 0.01 & 0.008 & 170 & 0.43 \\
\hline 29 & 45 & 0 & 0.6 & 0.1 & 0.029 & 170 & 0 \\
\hline 45 & 46 & 8 & 1 & 0.055 & 0.0185 & 150 & 0.72 \\
\hline 23 & 47 & 0 & 1.4 & 0.1 & 0.008 & 170 & 0 \\
\hline 43 & 48 & 4 & 1 & 0.055 & 0.0185 & 150 & 2.82 \\
\hline 20 & 49 & 0 & 1.4 & 0.01 & 0.008 & 170 & 0 \\
\hline 35 & 50 & 8 & 0.0486343 & 0.055 & 0.0185 & 150 & 0.81 \\
\hline
\end{tabular}

Table 2: Experimental data obtained for positive response variables obtained from Plackett-Burman in CCD.

agitation rate could result in enzyme inactivation due to shearing effect [25].

ANOVA of the cubic regression model suggested that the model was very significant as was evident from coefficient of variation $(\mathrm{CV} \%=65.19)$, low Standard deviation $(0.37)$, high determination coefficient $R^{2}$ of $0.9505(\mathrm{p}<0.0001)$, high adj. $R$-squared value $(0.67)$ and 
Citation: Reena G, Pooja K, Nitish S (2016) Statistical Optimization of Production Conditions of Alkaline Pectin Lyase from Bacillus cereus using Response Surface Methodology. J Food Ind Microbiol 2: 113. doi:10.4172/2572-4134.1000113

Page 4 of 7

\begin{tabular}{|c|c|c|c|c|c|c|}
\hline \multicolumn{7}{|c|}{ Analysis of variance table [Partial sum of squares - Type III] } \\
\hline Source & Sum of Squares & dF & Mean Square & F Value & $P$ value Prob $>$ F & Remark \\
\hline Model & 22.4971 & 20 & 1.12485 & 6.00295 & 8.414E-06 & Significant \\
\hline A-pectin & 2.73712 & 1 & 2.73712 & 14.6071 & 0.0006474 & \\
\hline B-sodium carbonate & 0.55861 & 1 & 0.55861 & 2.98112 & 0.0948809 & \\
\hline C-manganese sulphate & 2.9E-05 & 1 & 2.9E-05 & 0.00016 & 0.9901317 & \\
\hline D-magnesium sulphate & 0.02073 & 1 & 0.02073 & 0.11065 & 0.7417981 & \\
\hline E-RPM & 1.88864 & 1 & 1.88864 & 10.079 & 0.0035393 & \\
\hline$A B$ & 0.00285 & 1 & 0.00285 & 0.01523 & 0.902626 & \\
\hline$A C$ & 0.17925 & 1 & 0.17925 & 0.9566 & 0.3361335 & \\
\hline$A D$ & 0.01976 & 1 & 0.01976 & 0.10543 & 0.7477355 & \\
\hline $\mathrm{AE}$ & $9 \mathrm{E}-05$ & 1 & $9 \mathrm{E}-05$ & 0.00048 & 0.9826312 & \\
\hline$B C$ & 0.10806 & 1 & 0.10806 & 0.57668 & 0.4537466 & \\
\hline $\mathrm{BD}$ & 0.03575 & 1 & 0.03575 & 0.19081 & 0.6654801 & \\
\hline BE & 0.07852 & 1 & 0.07852 & 0.41901 & 0.5225242 & \\
\hline CD & 0.62834 & 1 & 0.62834 & 3.35324 & 0.0773651 & \\
\hline CE & 0.04239 & 1 & 0.04239 & 0.22622 & 0.6379043 & \\
\hline $\mathrm{DE}$ & 0.18 & 1 & 0.18 & 0.96061 & 0.3351387 & \\
\hline$A^{2}$ & 9.16285 & 1 & 9.16285 & 48.899 & $1.091 \mathrm{E}-07$ & \\
\hline $\mathrm{B}^{2}$ & 0.17347 & 1 & 0.17347 & 0.92573 & 0.3439301 & \\
\hline $\mathrm{C}^{2}$ & 0.67777 & 1 & 0.67777 & 3.61701 & 0.0671671 & \\
\hline$D^{2}$ & 0.30544 & 1 & 0.30544 & 1.63003 & 0.2118279 & \\
\hline$E^{2}$ & 0.37314 & 1 & 0.37314 & 1.99131 & 0.1688426 & \\
\hline Residual & 5.43412 & 29 & 0.18738 & & & \\
\hline Lack of Fit & 5.27672 & 20 & 0.26384 & 15.0859 & 0.0001175 & Non- significant \\
\hline Pure Error & 0.1574 & 9 & 0.01749 & & & \\
\hline Cor Total & 27.9312 & 49 & & & & \\
\hline
\end{tabular}

Table 3: Model analysis using ANOVA test.

Summary (detailed tables shown below)

\begin{tabular}{|l|l|l|l|l|l|}
\hline & Sequential & Lack of Fit & Adjusted & Predicted \\
\hline Source & p-value & p-value & R-Squared & R-Squared \\
\hline Linear & 0.0156 & $<0.0001$ & 0.1817 & 0.0643 \\
\hline 2FI & 0.9721 & $<0.0001$ & 0.0306 & -0.3250 \\
\hline Quadratic & $<0.0001$ & 0.0001 & 0.6713 & 0.0424 \\
\hline Cubic & 0.2446 & $<0.0001$ & 0.7572 & Suggested & \\
\hline
\end{tabular}

Table 4: Lack of fit for CCD showing model summary.

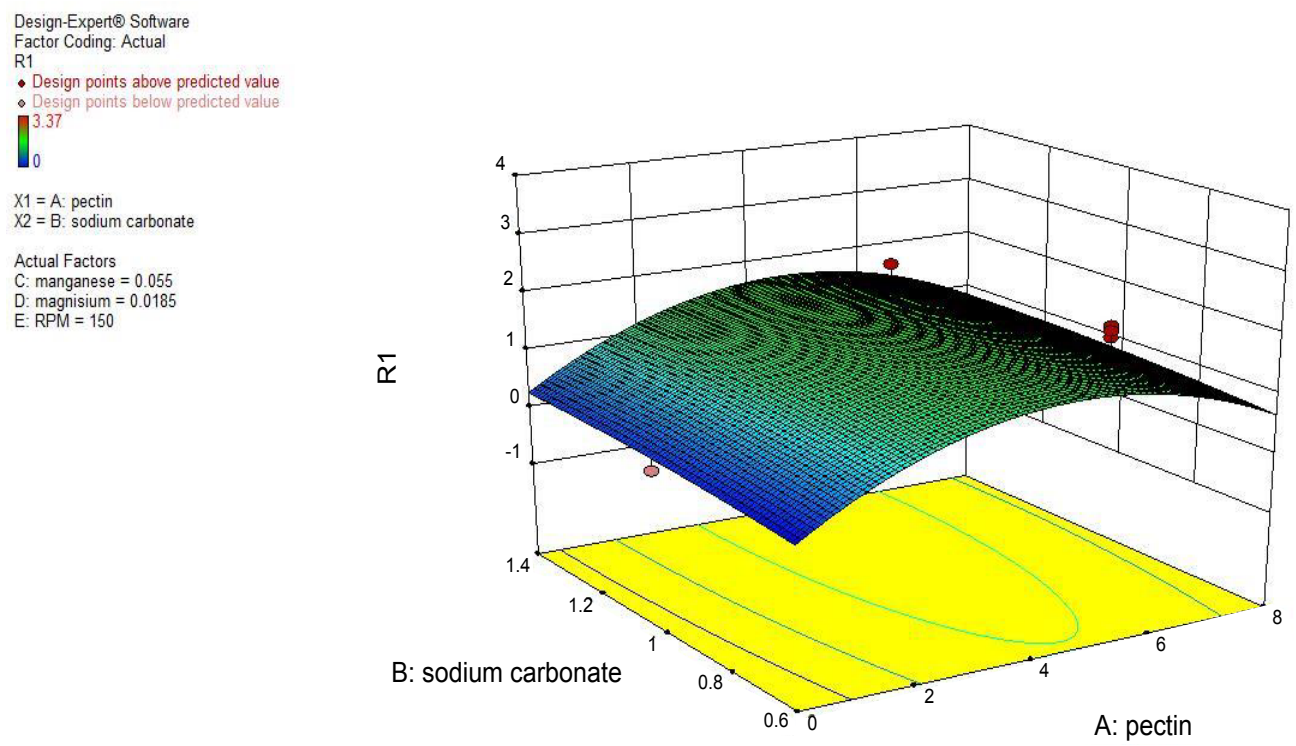

Figure 2: It represents the moderate interaction between sodium carbonate and pectin. Neither high nor low concentration of sodium carbonate and pectin gave higher enzyme yield. $4 \%$ pectin and $1 \%$ sodium carbonate gave optimum yield of enzyme but pectin had distinct impact on enzyme production in comparison to sodium carbonate. 
Citation: Reena G, Pooja K, Nitish S (2016) Statistical Optimization of Production Conditions of Alkaline Pectin Lyase from Bacillus cereus using Response Surface Methodology. J Food Ind Microbiol 2: 113. doi:10.4172/2572-4134.1000113

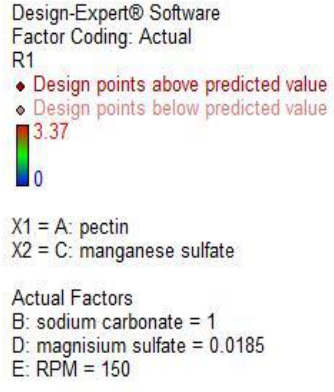

$\bar{\alpha}$

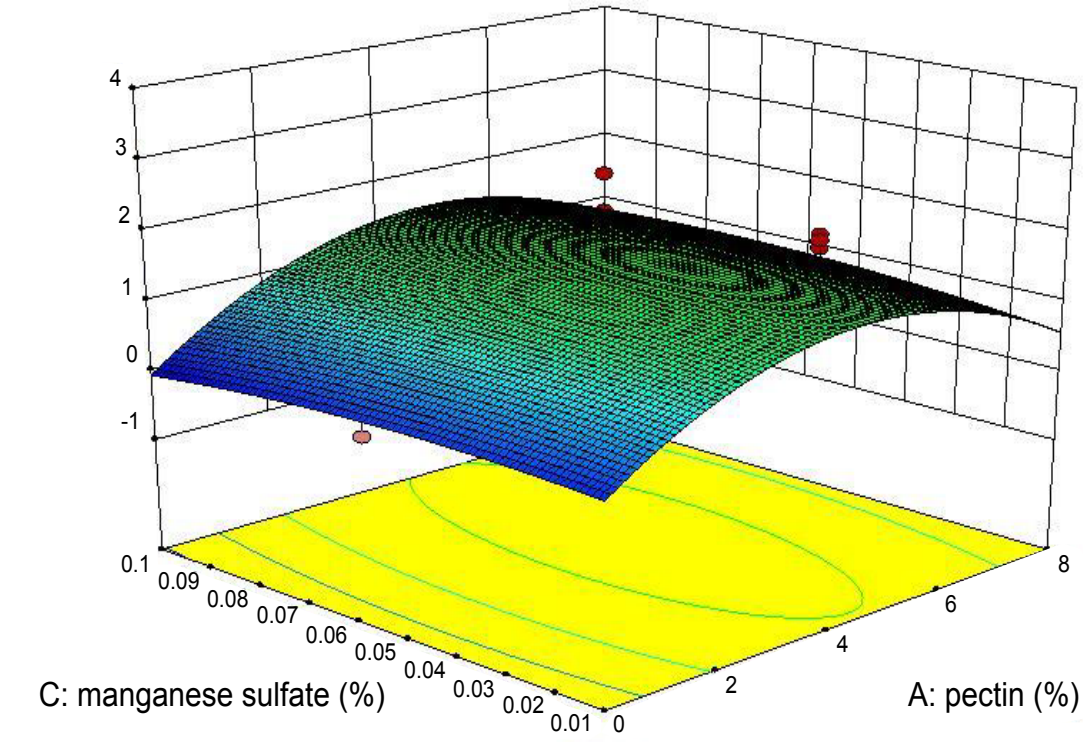

Figure 3: It represents the moderate interaction between manganese sulfate and pectin. Neither high nor low concentration of sodium carbonate and pectin gave higher enzyme yield. $0.055 \%$ manganese sulfate and $4 \%$ pectin gave optimum yield of enzyme but pectin had distinct impact on enzyme production in comparison to manganese sulfate as the pectin is inducer for the production of pectin lyase.
Design-Expert@ Software

Factor Coding: Actual

R1

- Design points above predicted value

- Design points below predicted value

?3.37

$\mathrm{X} 1=\mathrm{A}:$ pectin

$\mathrm{X} 2=\mathrm{D}$ : magnisium sulfate

Actual Factors

B: sodium carbonate $=1$

C: manganese sulfate $=0.055$

E: $R P M=150$ $\bar{x}$

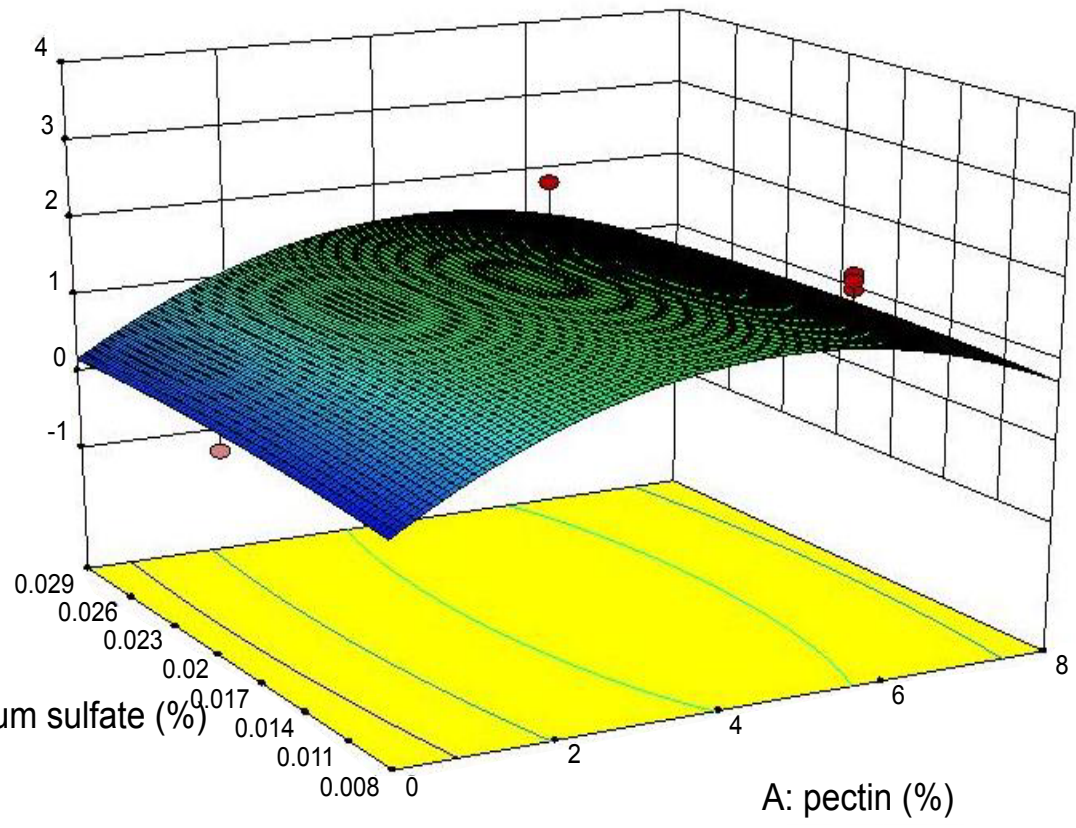

Figure 4: It represents the moderate interaction between magnesium sulfate and pectin. Neither high nor low concentration of magnesium sulfate and pectin gave higher enzyme yield. $0.0185 \%$ magnesium sulfate and $4 \%$ pectin gave optimum yield of enzyme but pectin had distinct impact on enzyme production in comparison to magnesium sulfate. 
Citation: Reena G, Pooja K, Nitish S (2016) Statistical Optimization of Production Conditions of Alkaline Pectin Lyase from Bacillus cereus using Response Surface Methodology. J Food Ind Microbiol 2: 113. doi:10.4172/2572-4134.1000113

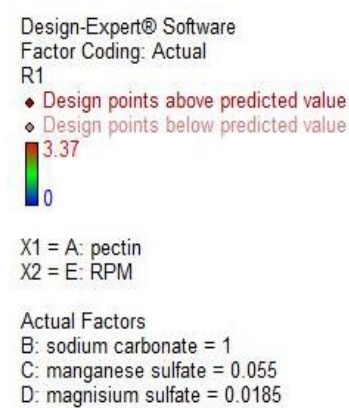

C: manganese sulfate $=0.055$

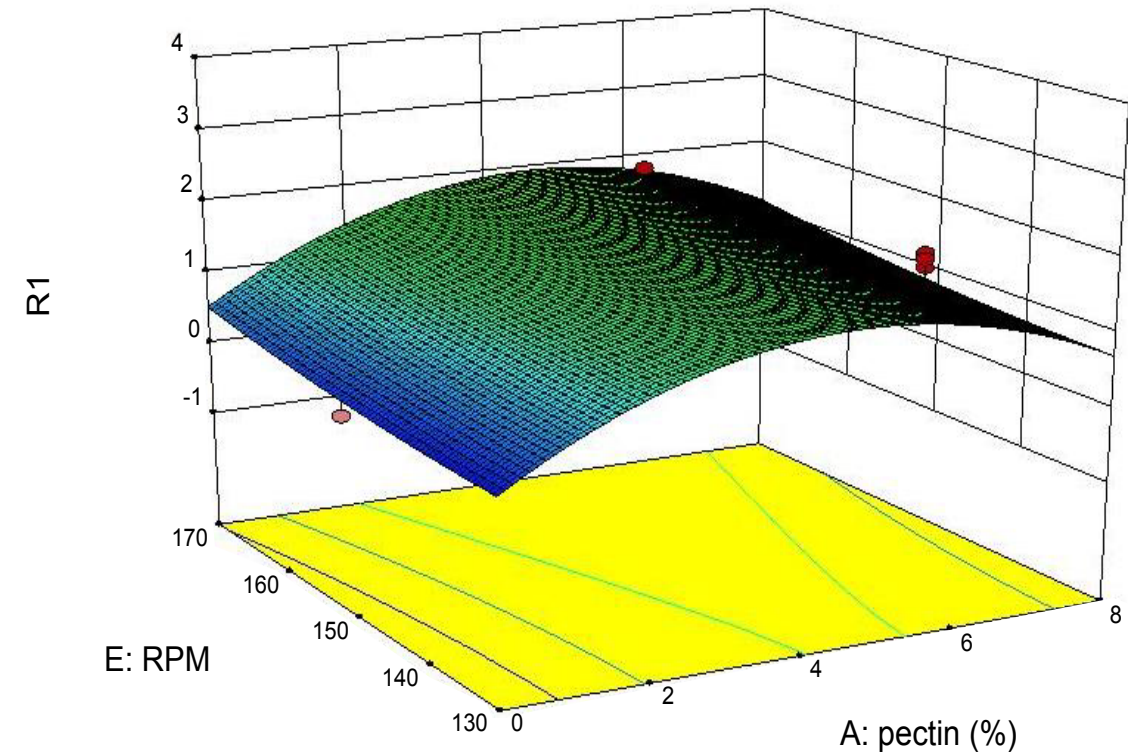

Figure 5: It represents that the interaction between rpm and pectin has cumulative impact on enzyme production. Neither high nor low concentration of pectin gave higher enzyme yield. $197 \mathrm{rpm}$ and $4 \%$ pectin gave optimum yield of enzyme. Yield increased with increase in rpm.

\begin{tabular}{|l|l|l|l|}
\hline S.D & 0.37 & R-Squared & 0.9505 \\
\hline Mean & 0.66 & Adjusted R-Squared & 0.6713 \\
\hline C.V \% & 65.19 & Predicted R-Squared & 0.0424 \\
\hline PRESS & 26.75 & Adequate Precision & 11.269 \\
\hline
\end{tabular}

Table 5: Model summary statistics.

low pressure value (26.75) Table 5. The $\mathrm{R}^{2}$ value indicated goodness of fit of model, but high $\mathrm{R}^{2}$ may be due to other non-significant variables and adj. R-squared value must be considered to manage the $\mathrm{R}^{2}$ [26]. Similarly, in other studies RSM was carried out for optimization and the adj. $\mathrm{R}^{2}$ (adjusted coefficient of determination) obtained was 0.37 , which was also high and indicated a significance of the model with $\mathrm{p}$ value $<0.05[27,28]$.

\section{Validation of model}

The RSM adequacy was shown by comparing the experimental data and the predicted values, which is performed by generating a fitted line plot (with experimental values on $\mathrm{X}$-axis and predicted values on Y-axis) for the obtained results, showing its closeness or deviation from the fitted line Figure 6. There was a good agreement between the experimental and predicted values. The maximum activity obtained by performing RSM was $3.37 \mathrm{U} / \mathrm{ml}$ which is close to the predicted value $2.69 \mathrm{U} / \mathrm{ml}$ as calculated by ANOVA test. The figure showed the overall closeness of selected variables, thus indicating that the response surface model is adequate for predicting the pectin lyase characteristics. A perturbation plot was also obtained Figure 7 that showed optimum values of variables for pectin lyase production from Bacillus cereus.

\section{Conclusion}

The optimum values of variables obtained from CCD analysis for pectin lyase production were pectin $4 \%(\mathrm{w} / \mathrm{v})$, sodium carbonate $1 \%(\mathrm{w} / \mathrm{v})$, manganese sulfate $0.055 \%(\mathrm{w} / \mathrm{v})$, and magnesium sulfate

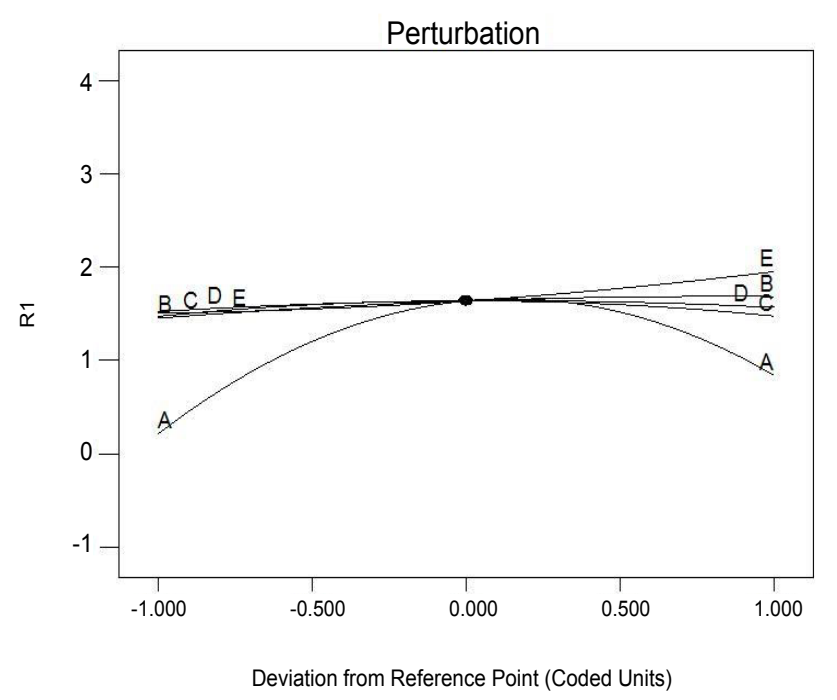

Figure 6: Perturbation graph showing impact of all variables considered in CCD on pectin lyase production.

$0.018 \%(\mathrm{w} / \mathrm{v})$ at $150 \mathrm{rpm}$. After optimization of different production parameters, pectin lyase activity from Bacillus cereus increased by 1.32 fold $(32.16 \%)$. Pectin had the most distinct impact on enzyme production in comparison to other variables being inducer for the production of pectin lyase. At present very few reports are available in literature regarding the statistical optimization of production conditions for pectin lyase and could serve as a base knowledge of initial studies in this field. 
Citation: Reena G, Pooja K, Nitish S (2016) Statistical Optimization of Production Conditions of Alkaline Pectin Lyase from Bacillus cereus using Response Surface Methodology. J Food Ind Microbiol 2: 113. doi:10.4172/2572-4134.1000113

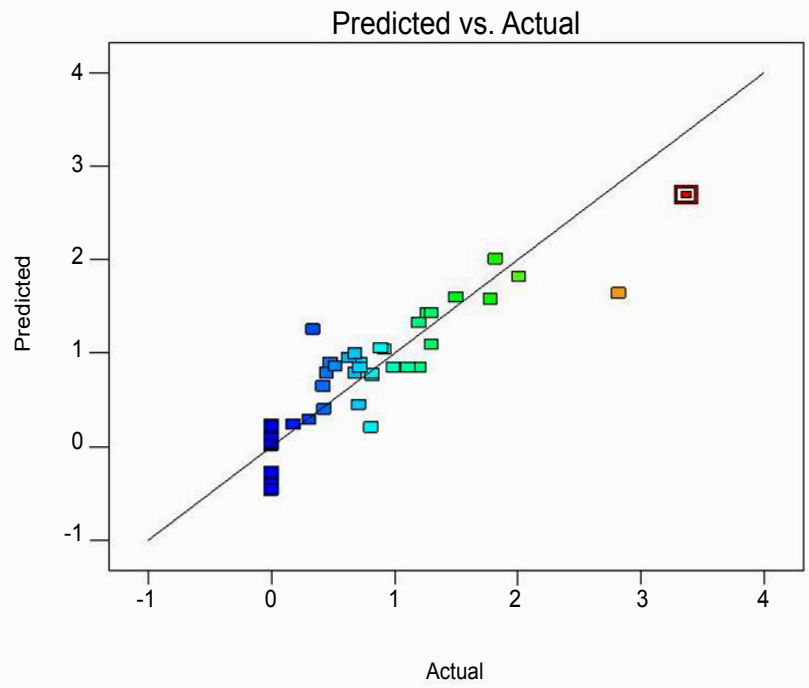

Figure 7: Comparison between predicted and actual response values.

\section{Acknowledgement}

The financial support to authors from Ministry of Science and Technology, Government of India, to the Department of Biotechnology, Himachal Pradesh University, Shimla (India), is thankfully acknowledged.

\section{References}

1. Yadav S, Yadav PK, Yadav D, Yadav KDS (2009) Purification and characterization of pectin lyase produced by Aspergillus terricola suitable for retting of natural fibers. Appl Biochem Biotechnol 159: 270-283.

2. Lionetti V, Cervone F, Bellincam D (2012) Methyl esterification of pectin plays a role during plant-pathogen interactions and affects plant resistance to diseases. J. Plant Physiol 169: 1623-1630.

3. Torres-Favela E, Aguilar C, Esquivel-Contreras CJ, Gustavo GV (2003) Pectinase in Enzyme Technology. Asiatech Publisher Inc.

4. Tariq A, Latif $Z$ (2012) Isolation and biochemical characterization of bacterial isolates producing different levels of polygalacturonases from various sources. Afr J Microbiol Res 6: 7259-7264.

5. Yadav S, Yadav PK, Yadav D, Yadav KDS (2008) Purification and characterization of an alkaline pectin lyase from Aspergillus flavus. Process Biochem 43: 547-552.

6. Esfanjani AF, Jafari SM, Assadpoor E, Mohammadi A (2015) Nanoencapsulation of saffron extract through double-layered multiple emulsions of pectin and whey protein concentrate. J Food Eng 165: 149-155.

7. Muslim SN, Israa MS, Kadmy AL, Mahammed AN, Musafer HK (2015) Detection of the optimal conditions for pectate lyase productivity and activity by Erwinia chrysanthemi. J Medical Bioeng 4: 184-191.

8. Bas D, Boyaci IH (2007) Modeling and optimization I: Usability of response surface methodology. J Food Eng 78: 836-845.

9. Box GEP, Wilson KB (1951) On the experimental attainment of optimum conditions. J. R. Stat. Soc. Series B 13: 1-45.

10. Mohandas BS, Prabhakar A, Rao RRK, Madhu GM, Rao GH (2010) Statistical optimization and neural modeling of amylase production from banana peel using Bacillus subtilis MTCC 441. Int J Food Eng 6: 1-6.

11. Chen QH, He GQ, Ali Mokhtar AM (2002) Optimization of medium composition for the production of elastase by Bacillus sp. EL31410 with response surface methodology. Enzyme Microb Technol 30: 667-672.

12. Montgomery DC (2001) Design and analysis of experiments. John Wiley and Sons, USA.

13. Kumar V, Kumar V, Bhalla TC (2015) Statistical enhancement of cyanide degradation using microbial consortium. J Microbial Biochem Technol 7: 344-350.
14. Bajaj BK, Singh S, Khullar M, Singh K, Bhardwaj S (2014) Optimization of fibrinolytic protease production from Bacillus subtilis 1-2 using agro-residues. Braz Arch Biol Technol 15: 653-662.

15. Quintavalla S, Paralari G (1993) Effects of temperature, aw and $\mathrm{pH}$ on the growth of Bacillus cells and spores: a response surface methodology study. Int J Food Microbiol 19: 207-216

16. Zohdi NK, Amid MA (2013) Optimization of extraction of novel pectinase enzyme discovered in Red Pitaya (Hylocereus polyrhizus) peel. Molecules 18 14366-14380.

17. Nedjma M, Hoffmann N, Belarbi A (2001) Selective and sensitive detection of pectin lyase activity using a calorimetric test: application to the screening of microorganism possessing pectin lyase activity. Anal Biochem 291: 290-296.

18. Bhatia SK, Mehta PK, Bhatia SK, Bhalla TC (2013) An isobutyronitrile-induced bienzymatic system of Alcaligenes sp. MTCC 10674 and its application in the synthesis of a-hydroxyisobutyric acid. Bioprocess Biosys Eng 36: 613-625.

19. Xiao ZJ, Liu PH, Qin JY, Xu P (2007) Statistical optimization of medium components for enhanced acetoin production from molasses and soybean meal hydrolyzate. Appl Microbiol Biotechnol 74: 61-68.

20. Wang Q, Fan XR, Hua ZZ, Chen J (2007) Optimizing bioscouring condition of cotton knitted fabrics with an alkaline pectinase from Bacillus subtilis WSHB0402 by using response surface methodology. Biochem Eng J 34: 107-113.

21. Songpim M, Vaithanomsat P, Yongsmith B, Chuntranuluck S (2011) Optimization of pectate lyase production from Paenibacillus polymyxa N10 in submerged fermentation using response surface methodology. Kasetsart $J$ (Nat. Sci.) 42: 191-197.

22. Zambare VP (2011) Optimization of amylase production from Bacillus sp. using statistics based experimental design. Emir J Food Agric 23: 37-47.

23. Ibrahim NA, El-Hossamy M, Morsy MS, Eid BM (2004) Development of new eco- friendly options for cotton wet processing. J Appl Polym Sci 93: 18251836.

24. Yadav KK, Garg N, Kumar D, Kumar S, Singh A (2015) Application of response surface methodology for optimization of polygalacturonase production by Aspergillus niger. J Environ Biol 36: 255-259.

25. Feng Y, He Z, Ong SL, Hu J, Zhang Z (2003) Optimization of agitation, aeration and temperature conditions for maximum $\beta$-mannanase production. Enzyme Microb Technol. 32: 282-289.

26. Shanthi V, Roymon MG (2015) Response surface optimization of xylanase production by indigenous thermoalkalophillic Bacillus sp. Afr J Microbial Res 9: 1699-1705.

27. Trupkin L, Levin F, Viale A (2003) Optimization of a culture medium for ligninolytic enzyme production and synthetic dye decolorization using response surface methodology. J Ind Microbiol Biotechnol 30: 682-690.

28. Olivera FC, Caron GR, Brandelli A (2004) Bacteriocin production by Bacillus licheniformis strain P40 in cheese whey using response surface methodology. Biochem Eng J 21: 53-58. 